Síntese: Revista de Filosofia adere a uma Licença

\title{
AO NOSSO MESTRE
}

\author{
To our master
}

\author{
Arnaldo Fortes Drummond *
}

Sumário: Este artigo realça a importância da vida e obra de Padre Vaz através de seu pensamento e da docência. Ele mostra que sua orientação identifica a raiz da crise contemporânea na ética e ressalta a atualidade do pensamento de Hegel como meio para superá-la. A interpretação hegeliana de Padre Vaz é examinada, sobretudo, através do livro Escritos de filosofia IV no qual resume o pensamento de Hegel cujo sistema localiza, na ideia da liberdade em si e para si, o fundamento metafísico de uma sociedade ética e politicamente construída. Esse fundamento, no qual Hegel baseou a teoria do estado, refuta a acepção subjetivista de liberdade no pensamento moderno - sobretudo o liberal - que, segundo Padre Vaz, é também responsável pela crise ética contemporânea. Para ele, a crítica de Hegel ao liberalismo pode ser aplicada ao materialismo histórico de Marx e ao socialismo real dele derivado, porque ambos, por razões distintas, não efetivaram a concepção verdadeira de liberdade na organização das nações e na determinação de seu destino; liberdade esta], que deve ser exercida pelo próprio cidadão não, em nome dele.

Palavras-chave: Ética. Metafísica da liberdade. Filosofia política. Filosofia da economia. Materialismo histórico.

Abstract: This article highlights the importance of Father Vaz's life and work through his thought and teaching. It shows that his thinking places ethics at the root of the contemporary crisis and highlights the permanent value of Hegel's thinking as a means to overcome it. Father Vaz's Hegelian interpretation is mainly examined through his book Escritos de filosofia IV (Writings of Philosophy IV), in which he summarizes Hegel's thought, whose system places the metaphysical foundation of an ethically and politically constructed society in

* Doutor em filosofia, professor aposentado, ex-aluno e orientando de Padre Vaz. Artigo recebido em 15/02/2021 e aprovado para publicação em 25/02/2021. 
the idea of freedom in and for itself. This foundation, at the basis of Hegel's theory of the state, refutes the subjective meaning of freedom in modern thought - especially the liberal - which, according to Father Vaz, is also responsible for the contemporary ethical crisis. For him, Hegel's criticism of liberalism can be applied to Marx's historical materialism and to real socialism, which derives from the former, since both, for different reasons, have not implemented the true conception of freedom in the organization of nations nor in the determination of their destiny; a freedom that ought to be exercised by the citizens themselves and not only in their name.

Keywords: Ethics. Metaphysics of freedom. Political philosophy. Philosophy of economics. Historical materialism.

$\mathrm{N}$ este memorial comemorativo ao centenário de nascimento de Padre Vaz, compartilho o testemunho de reconhecimento eterno ao notável mestre que orientou pessoalmente três gerações e cuja obra filosófica, incluindo manuscritos e gravações de suas aulas ${ }^{1}$ é marco inigualável da filosofia brasileira.

Quando o procurei em 1991, queria ouvir do pensador mineiro, conhecedor profundo da filosofia ocidental e das ciências humanas, como entender o impasse do pensamento humanista diante do colapso do socialismo real que ocorria na União Soviética e países do leste europeu. A exemplo do filho pródigo, o socialismo real voltava aos moldes anteriores do sistema capitalista com o qual havia rompido através do evento político mais radical e promissor do século XX, a revolução russa de 1917. Como militante de esquerda e professor de economia, eu me incluía nesse impasse, diante dos fatos que contrariavam os fundamentos de minha formação. Havia dedicado meus estudos à comparação dos sistemas econômicos, capitalista e socialista, e, à luz do marxismo, sabia que a roda da história não anda para trás. Por isso, parecia incompreensível o colapso de um sistema econômico historicamente à frente do outro, a ponto de regredir ao sistema anteriormente negado, por mais importante que fosse a crise em que se encontrava.

Desde a conversa preliminar que marcou o início da orientação do meu mestrado, Padre Vaz afirmou, de modo sucinto, que a raiz do impasse da sociedade contemporânea não era econômica e sim, ética. Enfatizou que a ética era uma área exclusiva da filosofia, embora, desde a Ilustração, outras disciplinas ousassem tratá-la, porém sob o domínio equivocado de racionalidades operacionais das ciências empíricas e humanas. Ele me

\footnotetext{
${ }^{1}$ Esses cursos, que terminaram em 1986 quando Padre Vaz se aposentou na UFMG, estão sendo publicados pelo Memorial Padre Vaz, na FAJE, sob coordenação do Pe. João Mac Dowell. Neste projeto editorial Obra filosófica inédita de Henrique Cláudio de Lima Vaz, do qual tenho a honra de participar, publiquei como editor A formação do pensamento de Hegel (2014) e Introdução ao pensamento de Hegel (tomo I, 2020).
} 
recomendou então estudar ética a partir de Aristóteles (384-322 a.C.) que sistematizou inicialmente os fundamentos científicos da disciplina. Foi o início da mudança de rumo da minha vida acadêmica que me levaria, no mestrado e doutorado, em direção aos estudos filosóficos para tratar a crítica aos fundamentos da economia.

De suas orientações profundas e objetivas, do seu curso de filosofia clássica a que assisti e gravei, dos inúmeros artigos de sua autoria que li e a que sempre recorro, enfim, dos escritos filosóficos que enfeixam o seu pensamento e são para mim objeto de consulta permanente, pude extrair e compreender os fundamentos da ética: o saber da práxis (perfeição do agir), na filosofia clássica (Platão, sobretudo Aristóteles) e o saber da liberdade, na filosofia moderna e contemporânea. E pude compreender que, além de equacionar cientificamente a prevalência da ética sobre a economia, esses fundamentos fazem a crítica radical, porque filosófica, ao liberalismo e ao socialismo real.

Sob orientação de Padre Vaz no mestrado, tratei o tema ético na economia e o aprofundei no doutorado, ${ }^{2}$ comparando a filiação dos modelos econômicos e éticos de Aristóteles e Adam Smith (1723-1790), pai da economia liberal. A economia aristotélica é apêndice do agir humano (práxis) e está, portanto, sob os domínios da moral e da convenção política. Pensador do empirismo, Smith separou a moral da ciência. A moral está situada no campo do sentimento no qual não há ciência e sim, valor. A economia é ciência porque está sob o domínio do fato do mercado. Baseado em Aristóteles, argumentei que não se separam moral e ciência, pois a mais simples relação econômica, o intercâmbio ou a troca direta implica reciprocidade, pressupondo por isso a determinação de uma norma ou convenção que é, respectivamente ética, ou norma justa, e política, ou norma geral. A norma é a convenção por excelência do interesse público. Isso me abriu nova perspectiva para criticar os fundamentos da economia, segundo a filiação ao mundo ético e político e não, segundo uma espécie de ciência natural, como faz a teoria liberal, e mais ainda, a neoliberal, ao subordiná-la ao princípio absoluto da regulação exclusiva de mercado. Na Ética a Nicômaco 5.5 e na Política 1. 3-5, ao mostrar que a economia é, em última análise uma convenção, Aristóteles torna possível concluir que a teoria econômica liberal não é ciência, no sentido de uma regra a priori que lhe dê fundamento, mas uma doutrina e, portanto, produto de arranjos da sociedade, mais precisamente, dos interesses dominantes. ${ }^{3}$

\footnotetext{
${ }^{2}$ Fui orientado pelo professor Marcelo Perine, amigo e discípulo de Padre Vaz, que reforçou a linha de trabalho do mestrado.

${ }^{3}$ Em 2004, baseado nesse debate, publiquei Morte do mercado; ensaio do agir econômico cujo título à primeira vista pode sugerir apelo publicitário, uma vez que o mercado está aí, bem vivo. No entanto, Padre Vaz concordou com o título porque o livro pretendeu demonstrar que a política econômica de uma nação e dos povos em geral não pode ser dirigida pela pseudociência do mercado (lógica do mercado).
} 
Restava compreender a ética na acepção da filosofia moderna e contemporânea que considera a liberdade o seu núcleo e cuja realização é a raiz da crítica de Hegel ao liberalismo e, conforme Padre Vaz, pode ser aplicada ao socialismo real.

No final dos anos 1950, antes, portanto, do colapso do socialismo real, Padre Vaz escreveu três artigos sequenciais nos primeiros números da revista Síntese, ${ }^{4}$ comparando Hegel e Marx. Mostrava o impasse ético do materialismo histórico do jovem Marx ao considerar a emancipação do ser humano mediada essencialmente pela relação humana no mundo trabalho e não, conforme Hegel, pela liberdade. Padre Vaz já se dedicava ao estudo completo da obra dos dois pensadores. ${ }^{5}$ A partir de 1970, com a publicação de Senhor e o escravo: uma parábola da filosofia ocidental, ${ }^{6}$ demonstra conhecimento profundo do pensamento de Hegel que o credencia como seu intérprete brasileiro. Nesse ano, em homenagem ao bicentenário de nascimento de Hegel (1770), inicia curso sobre a Fenomenologia do Espírito e, pela abrangência e profundidade de sua abordagem, passa a tratar a obra de Hegel como iniciativa permanente do seu magistério na UFMG até se aposentar. A repercussão desses cursos ultrapassou os limites acadêmicos, e eles se tornaram concorridos no ambiente cultural de Belo Horizonte como cursos de Padre Vaz sobre Hegel.

Publicou dezenas de trabalhos, entre ensaios, artigos, comentários, além de muitos verbetes para enciclopédia, com interpretações relevantes sobre Hegel ou temas hegelianos, a grande maioria na revista Sintese, e depois, Síntese - Nova Fase, da qual passa a ser editor até seu falecimento. Além dos cursos, seus escritos tornaram-se a mais ampla contribuição brasileira para a compreensão do texto esquemático de Hegel.

Há um ensaio em especial que resume a qualidade da interpretação hegeliana de Padre Vaz, e que destaquei para comentar nesta homenagem. Trata-se do capítulo intitulado Modelo historicista: o idealismo alemão e a ética de Hegel, no seu tratado de ética filosófica, ${ }^{7}$ que resume o alcance geral de sua interpretação. Em poucas páginas, ele não apenas interpreta o sistema hegeliano, sua base histórica e filosófica - da Fenomenologia do

\footnotetext{
${ }^{4}$ LIMA VAZ, H.C. Marxismo e filosofia. Síntese Política, Econômica e Social, Rio de Janeiro, 1959, n.1, 2, 3. Essa série de artigos foi publicada em LIMA VAZ, H.C. Ontologia e história. São Paulo: Duas Cidades, 1968, reeditado sob o título LIMA VAZ, H.C. Escritos de filosofia VI; ontologia e história. São Paulo: Loyola, 2011.

${ }^{5}$ LIMA VAZ, H.C. Filosofia e forma de ação. In: Cadernos de filosofia alemã. São Paulo, no 2 (jun. 1997), 77-102.

${ }^{6}$ LIMA VAZ, H.C. Senhor e escravo; uma parábola da filosofia ocidental. Síntese Nova Fase. Belo Horizonte, v. 8, no 21, p. 7-29, 1981. Na expressão do jesuíta Paulo Menezes, hegeliano amigo de Padre Vaz, é um luminoso artigo.

${ }^{7}$ LIMA VAZ, H.C. Escritos de filosofia IV; introdução à Ética filosófica 1. São Paulo: Loyola, 1999, cap. 3.
} 
espirito à Enciclopédia das ciências filosóficas -, como deduz a chave heurística e hermenêutica que atualiza o pensamento de Hegel frente às filosofias posteriores, respondendo, assim, a crise ética do presente. Não cabe aqui expor os meandros desse ensaio cuja leitura é insubstituível e sim, o poder explicativo (fecundidade heurística) dessa chave hermenêutica para identificar a atualidade do pensamento hegeliano como sistema racional e livre (razão e liberdade) que rege a condição lógica e histórica do ser humano. Essa chave consiste em considerar a metafisica da liberdade o núcleo da ciência absoluta: a ideia da liberdade em si e para si em seu desdobramento histórico e sistemático é absoluta na condição cultural do ser humano. Padre Vaz a expressa no aforismo: Pensar a liberdade aparece como a indeclinável e mais essencial tarefa da filosofia. ${ }^{8} \mathrm{Ou}$, como já afirmara em outra passagem dos Escritos de filosofia III: Pensar a Liberdade ou unir dialeticamente Liberdade e Razão, eis a única tarefa da filosofia. ${ }^{9}$

Com base nessa chave, passemos ao ensaio de Padre Vaz.

Antes, porém, é preciso fazer ressalva ao termo metafísica para que não se entenda metafísica da liberdade na acepção de ideia irrealizável que os tempos pós-metafísicos tentam atribuir a toda metafísica. Traduzida em chave heurística e hermenêutica que Padre Vaz atribui ao pensamento de Hegel, a metafísica da liberdade é a ontologia da ideia (a ideia é ser), manifestando-se logicamente como espírito na ideia da liberdade (ideia absoluta em si e para si). Como afirma Padre Vaz, a liberdade é a face lógica (conceito) da face real do espírito no tempo (Natureza e História). Infinitamente assim, o espírito no tempo é propriamente espírito absoluto. Portanto, a metafísica da liberdade é a ideia absoluta realizando-se no espírito absoluto como metafísica da liberdade, ou ideia da liberdade enquanto vontade livre em si e para si.

O ensaio Modelo historicista: o idealismo alemão e a ética de Hegel vincula o pensamento hegeliano ao idealismo alemão, especialmente à historicidade de um modelo filosófico, segundo o sistema de uma tríade história - cultura - ethos. ${ }^{10}$ Começa pela tentativa de Kant, de atenuar o dualismo da subjetividade entre razão teórica e prática, na Crítica do Juízo, ${ }^{11}$ mas a articulação dos três elementos constitutivos de uma história plenamente filosófica foi elaborada pelos herdeiros kantianos, Fichte e, sobretudo Hegel. História, cultura e ethos são, no pensamento de Hegel, o único sistema ético de uma

\footnotetext{
${ }^{8}$ Id., p. 378.

${ }^{9}$ LIMA VAZ, H.C. Escritos de filosofia III. Filosofia e cultura. São Paulo: Loyola, 1997, p. 80.

${ }^{10}$ A história tem na cultura sua face propriamente humana, oposta à contingência e ao aleatório dos fatores naturais, a cultura tem no ethos suas razões normativas e sua teleologia imanente. (In: LIMA VAZ, H.C. Escritos de filosofia IV, p. 365).

${ }^{11}$ (...) mas sem pôr em questão seus fundamentos críticos (...) a abolição da incognoscibilidade da coisa-em-si, ou seja, sem a posição de um absoluto real como princípio unificador e fundante do Sistema. (Id, p. 368).
} 
metafísica da liberdade do espírito que não é apenas subjetivo e objetivo, mas absoluto.

Nenhum outro filósofo moderno, segundo Padre Vaz, deu maior importância à ética do que Hegel embora não tenha escrito obra dedicada especificamente à exposição das suas concepções éticas. ${ }^{12} \mathrm{E}$ nem seria necessário porque o princípio da ética hegeliana, segundo a metafísica da liberdade, está no coração da estrutura teórica ou lógica de sua filosofia do espírito absoluto. ${ }^{13}$

Nesse ensaio, a metafísica da liberdade é o fio condutor do pensamento de Hegel enquanto sistema total do espírito (razão e liberdade) que Padre Vaz propõe nas seguintes formulações homólogas: a) Ética na formação do Sistema, b) Ética no Sistema. ${ }^{14}$ Em suma, é o agir humano, enquanto metafísica da liberdade, na própria gênese do sistema, em sua formação e sua estrutura definitiva. A metafísica da liberdade forma e estrutura, portanto, a ética, a filosofia da história, da cultura, do direito, a filosofia política e, coroando o sistema, a filosofia do espírito absoluto. Segundo Padre Vaz, a liberdade, em nenhuma outra filosofia, antes e depois de Hegel, ganhou maior estatuto especulativo. Por isso, a ética enquanto metafísica da liberdade já está inserida na formação e na vida do sistema da filosofia hegeliana:

Os passos a serem percorridos na construção do Sistema como ideia da Liberdade - ou como Ética - são fundamentalmente quatro: o fenomenológico, o lógico, o natural e o espiritual. ${ }^{15}$

Eles se referem aos três 'programas' possíveis da leitura especulativa do Siste$m a^{16}$ nos três silogismos da liberdade no final da Enciclopédia. ${ }^{17}$ Entretanto, apenas o último silogismo traduz a plena realização da metafísica da liberdade porque expressa a ideia absoluta (conceito) na estrutura da ideia da liberdade - vontade livre em si e para si mesmo, infinitamente - que é, para Hegel, a ideia de filosofia, a única e verdadeira ciência.

\section{A - Metafísica da liberdade na fenomenologia do espirito}

O caminho fenomenológico é a primeira experiência do sistema antes da estrutura definitiva na Enciclopédia. Na Fenomenologia do espírito, esse caminho é a ciência da experiência da consciência: saber que, em seu desdobrar,

\footnotetext{
12 Id., p. 370.

${ }^{13}$ Id., p. $370-371$.

${ }^{14}$ Id., p. 371.

${ }^{15}$ Id., p. 380.

${ }^{16}$ Id., p. 380.

${ }^{17}$ HEGEL, G.W.F. Enciclopédia das ciências filosóficas, em compêndio; 1830. Trad. Paulo Meneses. São Paulo: Loyola, 1995, §§ 575-577.
} 
discursiva e dialeticamente, é a metafísica da liberdade na consciência de si, razão e espírito propriamente dito. Tal metafísica consiste na concordância absoluta do sujeito com o seu próprio saber que nada mais é do que a plena adequação livremente aceita no interior da consciência entre a certeza do sujeito e a verdade do objeto. O sujeito pressuposto dessa consciência é, pois, um sujeito universal, por isso, espirito cuja concordância absoluta (razão) e livremente aceita (liberdade) com o objeto do saber é, portanto, saber absoluto, em qualquer realização desse caminho fenomenológico do sistema. ${ }^{18}$

Recorrendo ao texto hegeliano da Fenomenologia, em confronto com a passagem acima, deste e de outros ensaios de Padre Vaz, ${ }_{1}^{19}$ conclui-se, por assim dizer, que a consciência individual subjetiva $(\mathrm{Eu})$ já se constitui espírito, pois é manifestação da ideia da liberdade como seu eixo estruturante na concordância livre (liberdade) da certeza subjetiva com a verdade objetiva no ato consciente ou saber absoluto. Assim, a Fenomenologia demonstra que todo ato consciente é determinado pelo saber absoluto. Por isso, Hegel substituiu a categoria consciência da metafísica da subjetividade (de Descartes a Kant, incluindo Fichte, passando pelo racionalismo e empirismo) pela categoria espirito. Para ele, não é a consciência que chega ao espírito. Contrariamente, é o espírito que está na consciência e a determina ao saber absoluto: a regra cognoscente do ato consciente na sua concretude. Assim, o saber absoluto é demonstrado no percurso fenomenológico como a regra básica do espírito conhecedor e livre através do qual o sujeito concretiza o saber no momento em que sabe. Essa regra (razão) bem como a concordância inerente a ela (liberdade) são, portanto, universais a qualquer consciência. Hegel desvenda que a consciência pertence ao espírito e é por ele determinada a realizar (concretizar) a verdade (saber) e a concordar livremente com essa determinação do saber, instituindo a liberdade como necessidade ou lei, moral e cognoscente de uma única razão, que ele denominou espírito.

Na Fenomenologia, Hegel considera "conceito" o conteúdo ético e cognoscente da liberdade e se expressa na concordância livre do espírito com o saber absoluto. Na Ciência da lógica, "conceito" é a ideia absoluta em si e para si. No ato de saber, então, o espírito está fenomenologicamente na liberdade e logica ou dialeticamente no mundo da ideia. O conceito, segundo Padre Vaz, é a face lógica da liberdade do Espírito cuja "face real" manifesta-se primeiramente como Eu (espírito subjetivo). ${ }^{20}$

\footnotetext{
${ }^{18}$ A plena adequação entre a Certeza (subjetiva) e a Verdade (objetiva) (...) [é] pressuposição subjetiva universal subjacente a qualquer exposição do Sistema. Apresenta-se então a sequência linear Lógica-Natureza-Espírito (1 ${ }^{\mathrm{O}}$ silogismo) [Enciclopédia § 575], como a primeira e mais óbvia possibilidade de leitura sistemática do ser em sua totalidade inteligível e, do ponto de vista da condição temporal do discurso humano, a mais fácil a ser seguida. LIMA VAZ, H.C. Escritos de filosofia IV; introdução à Ética filosófica 1, p. 380.

${ }^{19}$ LIMA VAZ, H.C. Senhor e escravo; uma parábola da filosofia ocidental.

${ }^{20}$ LIMA VAZ, H.C. Escritos de filosofia $I V$; introdução à Ética filosófica 1, p. 383.
} 
Na Fenomenologia do espírito, portanto, a metafísica da liberdade é o fio condutor do processo em que o Eu é a manifestação do Espírito que ocorre, na progressão da metafísica da liberdade ou ideia da liberdade enquanto vontade livre em si e para si, desde o grau inaugural de existência espiritual (Eu pensante) na certeza sensível da consciência. O sujeito Eu, uma vez que é sempre espírito, é movimento dialético de progressão da verdade em torno de si mesmo através da concordância e satisfação (liberdade) com a lei interior e necessária do saber absoluto. Essa lei é (saber absoluto) e, infinitamente, deve ser (ética) enquanto verdade que é necessidade lógica da liberdade; e a liberdade, por sua vez, a necessidade real (Natureza e História) do espírito no seu devir contínuo ou infinito como ideia da liberdade. Logo, o eixo de construção da Fenomenologia já é uma progressão da metafísica da liberdade (ciência e ética) segundo a interpretação do Sistema hegeliano sob o ponto de vista da hermenêutica ontológica do conceito de Liberdade. ${ }^{21}$ Padre Vaz conclui:

A fundamentação lógica da Ética hegeliana como Sistema da liberdade repousa, pois, na doutrina do conceito (...), o conhecer propriamente dito ou Ideia da Verdade e o querer ou Ideia do Bem; finalmente, a Ideia absoluta. ${ }^{22}$

Em seu desenrolar como vida e conhecimento, o espírito, na face lógica da liberdade (metafísica da liberdade), são os dois momentos constitutivos da ideia absoluta em si e para si (conceito).

\section{B - Metafísica da liberdade na ciência da lógica}

A filosofia também tem um começo que é, segundo Hegel, pensar o pensar enquanto ato livre do pensar. Esse ato é:

Colocar-se no ponto de vista em que é para si mesmo [pensar o pensar] e por isso se engendra e se dá seu objeto mesmo [ato livre de pensar] (...) É mesmo esse seu único fim, agir e meta: alcançar o conceito de seu conceito e assim a seu retorno sobre si e à sua satisfação [liberdade]. ${ }^{23}$

Derivado da acepção hegeliana de pensar da Ciência da lógica, o conceito, segundo afirma Padre Vaz:

é, rigorosamente, o resultado da dialética da essência como momento da reflexão em si mesma da imediatidade do ser e é, por sua vez, o ponto de partida abstrato de um novo movimento dialético que levará à Ideia absoluta. ${ }^{24}$

\footnotetext{
${ }^{21}$ Id. 378, nota 22. Na verdade, o discurso fenomenológico, na estrutura final com que Hegel o redigiu, exprime já a manifestação progressiva do Absoluto como Espírito infinito na consciência do sujeito ou espírito finito e assegura assim ao sujeito, uma vez elevado em nível do Saber absoluto, a possibilidade de dizer essa manifestação segundo a necessidade objetiva do discurso sistemático. Id., p. 382.

${ }^{22}$ Id., p. 385.

${ }^{23}$ HEGEL, G.W.F. Enciclopédia das ciências filosóficas em compêndio, §17.

${ }^{24}$ LIMA VAZ, H.C. Escritos de filosofia IV; introdução à Ética filosófica 1, p. 384, nota 33.
} 
Isso marcará a trajetória do ser como absoluto dever-ser na imanência do espírito no tempo (Natureza e História) cuja essência é a liberdade realizada. Em outras palavras, a essência do espírito é concretamente ética, e a ética, constituindo-se essencialmente como liberdade realizada do espírito no tempo, nada mais é do que a concretização da metafísica da liberdade enquanto ideia absoluta em si e para si ou conceito. Conceito que, para Hegel, é antes o princípio de toda a vida [do espírito], e assim, ao mesmo tempo, pura e simplesmente concreto. ${ }^{25}$

\section{C - Metafísica da liberdade na passagem da lógica à filosofia da natureza}

A ideia absoluta é a estrutura na qual o espírito se manifesta, exteriorizando-se em si como ideia na Filosofia da Natureza para interiorizar-se em si e para si na Filosofia do Espírito. Esse movimento dialético da ideia (conceito) se realiza porque o espírito concretiza o dever-ser da ação humana (práxis), mediado pela liberdade. Não há, portanto, dissociação de teoria e práxis no pensamento hegeliano, visto que é imanente à dialética do conceito a manifestação absoluta da liberdade - metafísica da liberdade. E, com tal, o espirito manifesta sua inteligibilidade radical na Natureza e na História e orienta para o Absoluto o movimento dialético dessa manifestação. ${ }^{26}$ Com isso, a manifestação do espírito como conceito é, afinal, ser como um dever ser necessário da liberdade em sua infinitude - natureza (ser) e história (dever ser) indissociados, na determinidade infinita da ideia de liberdade. A liberdade se autodetermina infinitamente como espírito absoluto no qual conceito e objeto são idênticos. ${ }^{27}$ Ela efetiva o espírito enquanto natureza, mas a metafísica da liberdade é ideia infinita que efetiva o espírito enquanto espírito e, portanto, retorno da alteridade da natureza para o espírito.

\section{D - Metafísica da liberdade na passagem da filosofia da natureza ao espirito}

$\mathrm{Na}$ passagem do espírito subjetivo ao espírito objetivo (ação ou obras concretas do espírito), Hegel explicita a realização ética da história, não como sucessão de eventos, mas como filosofia da história ou filosofia do direito. Nessa acepção, Padre Vaz destaca que história e direito são a efetivação da

${ }^{25}$ HEGEL, G.W.F. Enciclopédia das ciências filosóficas em compêndio, §160.

${ }^{26}$ LIMA VAZ, H.C. Escritos de filosofia IV; introdução à Ética filosófica 1, p. 387.

${ }^{27}$ Id., p. 388. 
liberdade realizada, uma vez que a interiorização da ideia pelo espírito só é real como auto-reconhecimento [liberdade] na ação ou nas obras concretas com que o Espírito realiza a Ideia no tempo e se faz História. ${ }^{28}$ Logo, a liberdade realizada é a efetivação do direito e da história na acepção propriamente filosófica que é o existir abrangente de todas as determinações da liberdade. ${ }^{29}$ Ela ultrapassa e determina, em última instância, o sentido limitado da realidade jurídica, ${ }^{30}$ implicando historicamente o jurídico na estrita correlação com o dever objetivo do ethos.

Desenvolver o tema da liberdade sob as formas do dever ser (ética) indissociado do ser (metafísica clássica) ou do saber (metafísica moderna) é o principal programa da filosofia do espírito objetivo de Hegel na Enciclopédia das ciências filosóficas, e na sua versão mais aprofundada, publicada à parte, Teoria do estado: linhas fundamentais da filosofia do direito ou direito natural e ciência do estado, em resumo. A filosofia do direito de Hegel consagra, nos termos de Padre Vaz, a ética (liberdade) no coração do sistema gnosiológico hegeliano e, por isso, ele é metafísica da liberdade. Desse modo, a ideia que se efetiva em conceito não é apenas ser ou saber, mas, em função da liberdade que a determina, é também dever ser. Logo, mediado pela metafísica da liberdade o que é, deve ser e vice-versa. É o que afirma Hegel, em outras palavras, no prefácio de sua filosofia do direito e que se tornou máxima incompreendida fora do pensamento hegeliano: o que é racional é real (efetivo) e o que é real (efetivo) é racional. ${ }^{31} \mathrm{O}$ real de Hegel é a efetividade completa ou total do saber: produção (razão) e reconhecimento (liberdade) articulados dialeticamente. Não é o real bruto externo à ideia, tampouco o fato bruto dos empiristas que separa a ciência da moral. A concepção hegeliana do real como efetividade da ideia (conceito) não provém, portanto, da razão abstrata do racionalismo nem reproduz a falácia naturalista da moral empirista que passa acriticamente do fato bruto à expressão inteligível do dever ser. ${ }^{32}$

Abordei, de passagem, a refutação kantiana ao argumento gnosiológico que levou o empirismo a separar moral e ciência. ${ }^{33}$ No entanto, Kant preparou, por assim dizer, o caminho da metafísica da liberdade para a refutação integral - isto é, nos domínios moral e científico - dos fundamentos da falácia naturalista dos empiristas. Hume notabilizou a expressão falácia naturalista ao atribuir grau de certeza ao que não é natural, como é o caso da moral, regida pela norma. A certeza rege o fato; o fato é, pois, natural. A

\footnotetext{
${ }^{28}$ Id., p. 389.

${ }^{29}$ Id., p. 390.

${ }^{30}$ Id., p. 390.

${ }^{31}$ HEGEL, G.W.F. Fundamentos de la filosofia del derecho. Edición: K.H.Ilting. Madrid: Libertarias/Prodhufi, 1993, p. 57.

${ }^{32}$ LIMA VAZ, H.C. Escritos de filosofia IV; introdução à Ética filosófica 1, p. 399.

${ }^{33}$ DRUMMOND, Arnaldo Fortes. Morte do mercado; ensaio do agir econômico. São Leopoldo: Ed. Unisinos, 2004, cap. 7.
} 
norma, por sua vez, não é fato, mas preceito e, portanto, dever ser. Querer atribuir a mesma regra ao que é (fato) e ao que deve ser preceito (moral) é um erro lógico, uma falácia naturalista. A refutação kantiana consistiu, grosso modo, em demonstrar que há no Eu penso uma razão pura prática que, regida pela liberdade, determina absolutamente como eu devo agir moralmente: o imperativo categórico. A liberdade que, para Kant, é a fonte absoluta da moral, nasce de uma vontade livre em si e, por isso, ele a considera um fato da razão pura em seu uso prático. Pela liberdade, no plano moral, mas não da ciência, o que é deve ser absolutamente (imperiosamente). Kant já desvenda, portanto, uma metafísica da liberdade que rege a moral (mas não, a ciência) e que ele denomina razão pura prática. Ultrapassando a crítica kantiana, Hegel desvenda a metafísica da liberdade em sua integralidade, no domínio moral e científico (gnosiológico), refutando os fundamentos da falácia naturalista. O é, na metafísica da liberdade hegeliana, deve ser, tanto moral como cientificamente, pois é absoluto ao espírito subjetivo o autorreconhecimento no momento concreto de manifestação da verdade moral e da verdade científica. Assim, na metafísica da liberdade não se passa "acriticamente" do fato ao princípio absoluto, como adverte acima Padre Vaz, apesar do fato bruto ainda prevalecer como fundamento gnosiológico das ciências naturais e humanas, a exemplo da teoria econômica liberal.

Ao igualar o racional ao real efetivo do saber, o aforismo hegeliano não considera, portanto, que o fundamento do espírito objetivo - o direito do espírito de existir - esteja no fato da sua existência, a exemplo da jusnaturalismo moderno, e sim, na efetividade da liberdade: $o$ reino da liberdade realizada. ${ }^{34}$

\section{1 - Metafísica da liberdade na filosofia do direito}

O programa da Filosofia do direito (FD) me interessou particularmente porque nele Hegel sistematiza a ciência do estado. Como Padre Vaz chama atenção nesse ensaio e em vários artigos, a ciência do estado de Hegel é a ciência da sociedade política, aquela que é regida pelos elementos essenciais da política e da ética. Na acepção hegeliana de Padre Vaz, essa ciência é metafísica da liberdade uma vez que ela se faz pela liberdade realizada na história, como espírito do tempo, mas, como metafísica, necessariamente ultrapassa infinitamente a história. Na FD, nasceu, portanto, a teoria política em sentido radical - ou seja, explicada pela raiz da sociedade política - e, como toda filosofia hegeliana, determinada pela ideia: a ideia da liberdade. Ela responde essencialmente o seguinte: uma ciência do estado - ou da sociedade política - tem como fundamento a liberdade realizada. E é o cida-

${ }^{34}$ HEGEL, G.W.F. Fundamentos de la filosofia del derecho, §4. 
dão quem realiza a liberdade em uma sociedade na qual todos participam (sociedade política. Ele é o poder soberano que governa permanentemente seu próprio destino, material e simbólico). Não se trata aqui de modelo particular de estado que transfere a soberania do cidadão para a instituição que o representa, a exemplo do liberalismo, o mais avançado à época de Hegel e que ainda é hegemônico. Não se trata igualmente de qualquer estado alternativo que pretenda representar o interesse público do cidadão através de princípio institucional absoluto que o representa, como na ditadura do partido único no socialismo real. Hegel não parte do fato bruto como determinante do real efetivo (falácia naturalista); caso contrário, ele teria considerado o liberalismo a última palavra em teoria social e política. Parte do pressuposto de que não há ideia da liberdade sendo realizada no liberalismo, isto é, o estado liberal é o estado da não-liberdade do cidadão, pois nele predomina a sociedade civil ou lógica do conflito de interesses. ${ }^{35}$

A FD não consagra o que é em sua factualidade nem o dever-ser a priori imposto à contingência e a história. ${ }^{36}$ Consagra assim a eticidade ou vida ética concreta: a síntese dos momentos teórico e prático do espírito, através da dialética da razão e liberdade que, nos termos da filosofia moderna, é a metafísica da liberdade. A ideia da liberdade em seu realizar ético (eticidade) obedece ao percurso da ideia na Lógica (ser, essência e conceito) que corresponde, respectivamente, na $\mathrm{FD}$, a direito abstrato (ser), moralidade (dever ser) e eticidade (conceito). A vida ética concreta é o conceito de convivência social traduzido em liberdade realizada nos três momentos (universal abstrato, particular, singular ou universal concreto). A eticidade reúne os três momentos básicos de sociabilidade: família, sociedade civil e estado (sociedade política). Como tratei em artigo, ${ }^{37}$ na família, a liberdade realizada é uma eticidade limitada aos laços (afetivos): é, pela lógica da ideia, universalidade abstrata. Na sociedade civil, a eticidade se particulariza no indivíduo independente; seu ethos é limitado pelo sistema de necessidade ou interesses particulares conflitantes que regem a vida social, como na sociedade liberal ou capitalista. A eticidade, pela lógica da ideia, é precária e se limita à escolha particular em disputa permanente. A sociedade civil requer, por isso, uma regulação institucional, com poder acima de todos, para manter o pacto de convivência. Para Hegel, a sociedade civil representa historicamente a eticidade capitalista ou liberal com o estado na função de pacto de convivência. $\mathrm{O}$ estado liberal, segundo ele, não tem função pública por essência. Ao contrário, administra conflitos privados e aplaca o estado de selvageria, na expressão hegeliana. A eticidade completa é a efetivação da ideia da liberdade; socialmente, ela se apresenta no estado ou sociedade política: a liberdade que quer a si mesma e que o indivíduo deve realizar como

\footnotetext{
${ }^{35}$ Id. $\S 183$.

${ }^{36}$ LIMA VAZ, H.C. Escritos de filosofia IV; introdução à Ética filosófica 1, p. 392.

${ }^{37}$ DRUMMOND, Arnaldo Fortes. Liberdade e economia na Filosofia do Direito de Hegel. Sintese. Belo Horizonte, v. 33, nº 107, 2006.
} 
seu fim. ${ }^{38}$ Nessa eticidade, o estado é o lugar privilegiado de manifestação do espírito subjetivo e objetivo, através do cidadão que detém o poder soberano e não, instituições que venham a representá-lo. O cidadão é o fim lógico e histórico dessa caminhada na construção de uma sociedade política hegeliana.

Segundo Padre Vaz, a sociedade política não é o último estágio do espírito para Hegel, por mais ampla que seja a manifestação histórica da liberdade nessa sociedade. A liberdade é ideia na acepção hegeliana, no seu infinito realizar e, como tal, é o querer livre em seu próprio exercício: é a metafísica da liberdade. Sua estrutura (vontade livre em si e para si) não se esgota, portanto, no produto de sua manifestação (a contingência ou contínuo fluir histórico) e sim, na própria ideia da liberdade: ideia se fazendo ideia na alteridade natural e histórica, mas retornando a si como espírito absoluto, sem se congelar no tempo. Hegel seria contraditório se paralisasse o exercício da liberdade do cidadão numa determinada instituição de caráter histórico. Ele aí sim, decretaria o fim da história como erroneamente foi interpretado pelo historicismo. A historicidade expressivista a ele atribuída, segundo Padre Vaz ${ }^{39}$, significa, contrariamente a esse congelamento do estado em instituições, que o espírito, apesar de histórico, não se delimita ao histórico. É, por assim dizer, meta-histórico devido à metafísica da liberdade: ideia absoluta em si e para si. O espírito sempre se ultrapassa historicamente pelo exercício lógico e absoluto do livre pensar:

a ideia eterna essente em si e para si, que eternamente se ativa, engendra,

e desfruta, como espírito absoluto. ${ }^{40}$

Toda pretensão de modelar institucionalmente o estado hegeliano ou os estados alternativos ao liberalismo, a exemplo do socialismo real na ex-URSS, cai no reducionismo historicista contra Hegel. No já citado prefácio da FD, ele mesmo advertira que a ciência do estado é um escrito filosófico e como tal visa a conhecer os elementos do estado racional em si como universo ético. ${ }^{41}$ Não se queira atribuir a Hegel modelo específico de estado. O cidadão da sociedade política hegeliana pressupõe, à luz da metafísica da liberdade, indivíduo engajado na condução dos destinos ou finalidade da condição humana e, por isso, da melhor sociedade. É o indivíduo universal: ética e politicamente educado.

$\mathrm{Na} F \mathrm{~F}$, nasce o tratado que decretou, por assim dizer, o fim do liberalismo, bem como de toda forma particular de estado que queira conceber erroneamente a liberdade realizada ou o estado de direito em instituições

\footnotetext{
${ }^{38}$ LIMA VAZ, H.C. Escritos de filosofia IV; introdução à Ética filosófica 1, p. 396/7.

${ }^{39} \mathrm{Id}$, p. 366.

${ }^{40}$ HEGEL, G.W.F. Enciclopédia das ciências filosóficas em compêndio, §17 e §577.

${ }^{41}$ HEGEL, G.W.F. Fundamentos de la filosofia del derecho, p. 58-59.

${ }^{42}$ Id., $\$ 22$.
} 
representativas. No jargão jurídico e sociológico atual, é muito comum falar de instituições do estado democrático de direito, a exemplo dos três poderes da república, como se eles, por si sós, atuassem com interesse público. Segundo a ciência do estado de Hegel, as instituições não atuam; quem o faz são os indivíduos que a elas pertencem. No entanto, como indivíduos particulares, representam a si mesmos, em caso de conflito com o interesse público, sobretudo na forma do interesse corporativo ou da classe social em que se situam. Falar de instituições democráticas é abstração; falar de indivíduos democráticos é real. Por outro lado, para ser democrático e fazer prevalecer o interesse público sobre o individual, o indivíduo tem de ser cidadão do estado ou da sociedade política. A ideia de liberdade, que o cidadão hegeliano encarna, é a vontade livre em si e para si. ${ }^{42}$

Padre Vaz conclui o ensaio com a análise do espírito absoluto: termo absoluto do sistema. ${ }^{43}$ Considera o curso real e lógico da ideia da liberdade no qual Hegel resume o que é filosofia ou ciência: ideia absoluta da liberdade realizando-se no silogismo entre o espírito e a natureza: E (filosofia do espírito) - L (lógica) - N (filosofia da natureza). Sobre tal silogismo, Hegel afirma:

Esse movimento é igualmente a atividade do conhecimento, a ideia eterna essente em si para si, que eternamente se ativa, engendra e desfruta, como espírito absoluto. ${ }^{44}$

O que é isso senão o que Padre Vaz caracterizou como metafísica da liberdade do espírito absoluto? A metafísica da liberdade é a essência da filosofia através do aforismo que ele cunhou nesse ensaio.

\section{Segundo Padre Vaz,}

a posteridade de Hegel, quase, sem exceção, se recusou a ouvi-lo, traçando assim o destino do historicismo na filosofia pós-hegeliana. De L. Feuerbach a A. Kojève, passando por K. Marx e por todas as variantes da tradição marxista, pelo historicismo idealista e culturalista, pela fenomenologia de cunho existencialista, a leitura de Hegel (...) deteve-se obstinadamente nas fronteiras da História e erigiu o paradigma de um antropologismo radical como único adequado a interpretar Hegel, mesmo contra Hegel (...) causa e efeito do clima anti-metafísico que começou a reinar na filosofia do século XIX depois de Hegel e prolonga-se mais ameno na filosofia do século XX, caracterizada como filosofia de uma idade pós-metafísica. ${ }^{45}$

E conclui que Hegel assumiu o empenho teórico de vincular

a mais ambiciosa tentativa de fundamentar e legitimar numa Razão universal o já multimilenar caminho da ação humana no tempo: sua natureza, suas peripécias e a imensa variedade de suas formas e obras. ${ }^{46}$

\footnotetext{
${ }^{43}$ LIMA VAZ, H.C. Escritos de filosofia IV; introdução à Ética filosófica 1, p. 402.

${ }^{44}$ HEGEL, G.W.F. Enciclopédia das ciências filosóficas, § 577.

${ }^{45}$ LIMA VAZ, H.C. Escritos de filosofia IV; introdução à Ética filosófica 1, p. 400.

${ }^{46}$ Id., p. 407.
} 
Em outras palavras, afirma o empenho teórico de Hegel, como nenhum outro filósofo desde a Antiguidade, em vincular metafísica, ética e política à ação humana universal (o espírito absoluto se resume a isto), agora sob a chave hermenêutica e heurística da metafísica da liberdade de Padre Vaz.

À luz desse ensaio, outros escritos e entrevistas de Padre Vaz, a teoria hegeliana do estado ultrapassa o liberalismo e as teorias posteriores, mesmo que seu tempo não tivesse presenciado outra organização política, social e econômica. No seu curso político, a ideia da liberdade é a eticidade ou ciência do estado, fundada na metafísica da liberdade e exercida historicamente pelo cidadão. Mas, a historicidade expressivista, como esse ensaio caracteriza o sistema hegeliano, implica a metafísica da liberdade na crítica filosófica que ultrapassa infinitamente o tempo pela ideia absoluta da liberdade.

\section{Conclusão}

Trinta anos se passaram da primeira conversa com Padre Vaz sobre o desafio de compreender o vínculo entre ética e economia. Nessa caminhada de muitas estações que mudou o rumo da minha vida acadêmica, fui aos poucos aprofundando o juízo inicialmente revelado por ele sobre a raiz de natureza ética da crise contemporânea. Os pálidos conhecimentos sobre ética me obrigaram a um longo percurso de estudos filosóficos para me aproximar do significado desse vocábulo. A palavra ética tornou-se usual para designar correção de comportamento e confunde-se com o discurso moral latente a todo propósito educacional, às intrincadas e complexas relações humanas da sociedade contemporânea. Transformou-se em jargão repetido aos quatro ventos desde as situações mais corriqueiras a quaisquer circunstâncias em desacordo com os costumes e hábitos ou quebra de um simples contrato. E todos sabem lidar perfeitamente com esse significado em tais circunstâncias. No entanto, não é na linguagem comum ligada a valores, costumes e sentimentos que o discurso moral revela o seu fundamento. Embora essenciais, eles são apenas a recepção do fundamento ético que se situa na racionalidade da alma (psiquê) ou do espírito $^{47}$ do ser humano. Foi assim que a filosofia clássica fundou a ética como ciência do agir humano (práxis).

Na observação inicial do nosso mestre, seria preciso que eu compreendesse os fundamentos dessa ciência, que rege de modo universal o comportamento

${ }^{47}$ Trato aqui essas noções provisoriamente como equivalentes, apesar do inesgotável repertório de nuances que as diferencia na história da filosofia. 
humano (ethos), para conseguir estabelecer o seu vínculo com a Economia que é um modo particular desse comportamento, por mais importante e necessário que seja à nossa sobrevivência.

No mestrado relacionei a economia à ética, de passagem, em Platão (República e Leis) e, sobretudo em Aristóteles (Ética a Nicômaco 5.5 e Política 1.3-5) que sistematiza as primeiras categorias da economia, tais como valor, dinheiro e medida (comensurabilidade), determinadas pela excelência ou perfeição (essência) do agir humano: a práxis. ${ }^{48}$ Ciência é o agir humano que, na perspectiva aristotélica da práxis, é a Ética para o indivíduo, e a Política, ou ética transposta para o social. Elas determinam o agir econômico, que é o modo universal de organizar a economia, e não, a organização econômica, particular e histórica, denominada genericamente economia.

Com isso, obtive a chave de interpretação e fundamento das reflexões posteriores: não é objeto de ciência e sim, de doutrina a organização de todos os sistemas econômicos particulares sistematizados até hoje - escravismo, feudalismo, capitalismo, socialismo. Ciência, e não doutrina, é compreendê-los segundo o modo excelente de organização humana - $o$ agir humano - que é essencialmente ético e político. A economia de uma sociedade ou de um período histórico é organização econômica determinada pela doutrina. Doutrina é obra de convenção, e não, ciência e, como tal, a universalidade a que visa é sempre subsumida ao juízo particular de caráter dominante em determinada época, a exemplo da teoria econômica liberal e do positivismo jurídico no direito.

No doutorado, aprofundei essa reflexão que resultou em livro, ${ }^{49}$ onde concluo que a metafisica e a ética de Aristóteles fundam uma concepção mais universal de organização econômica do que a de Adam Smith, cuja Riqueza das Nações (1776) inaugura a Economia política clássica como a ciência do liberalismo econômico. Adam Smith e David Hume foram protagonistas da concepção do moral sense que separa ciência e moral, baseados na observação do fato e do valor respectivamente. A ciência trata do que é; por isso, funda-se na certeza do fato; distintamente, a moral, por tratar da norma - o que deve ser -, e cuja observação não requer a certeza imediata do fato e sim, da recepção de um valor, situa-se no sentimento, a origem mais remota da ação. ${ }^{50}$

O mercado é para Smith amparado pela concepção de eficácia do fato na lei de oferta e procura e, por isso, passa a ser o regulador da economia, dissociando organização econômica e fundamento ético objetivo. Cabe, contudo, a ressalva de que Smith é, sobretudo, pensador moral e, por isso,

\footnotetext{
${ }^{48}$ Minha dissertação de mestrado tem o título Ética e Economia: abordagem da ontologia do agir econômico (FAFICH-UFMG/1997).

${ }^{49}$ DRUMMOND, Arnaldo F. Morte do mercado: ensaio do agir econômico (2004).

${ }^{50}$ Para Hume, o sentimento é o motor de onde provém o comando originário para que a vontade desencadeie a ação; a própria razão também é produto desse comando. DRUMMOND, op. cit., p. 153.
} 
resolveu a aporia entre moral e ciência antes de dissociar economia e o fundamento moral objetivo, no seu importante tratado Teoria do sentimento moral (1759). ${ }^{51}$ Ele agregou ao moral sense o que denominou sentimento da simpatia que, resumidamente, é a propensão natural do sentimento humano à sociabilidade. Por essa teoria, Smith concluiu que o indivíduo, portador natural desse sentimento, ainda que o experimente privadamente, como todo sentimento, é capaz de corrigir as injustiças e distorções que porventura tenha provocado, inclusive as derivadas do mercado. Smith resolve assim a separação objetiva entre ciência e moral, sem, porém, eliminar a moral da ação econômica por causa do sentimento social da simpatia. Por isso, na visão smithsoniana a lei do mercado é regida pela ciência, mas, ainda que privadamente, a moral do indivíduo participa da realização econômica, ao contrário do caráter moralmente neutro da ciência econômica do pensamento liberal posterior, revigorado pelo neoliberalismo do presente.

A crítica de Kant, no entanto, repõe o fundamento último da moral na razão, a exemplo de Aristóteles, superando em parte a moral abstrata do racionalismo anterior (Descartes a Christian Wolff) e a subjetividade privada do moral sense. Tornou-se então necessária a minha reflexão kantiana. Possibilitou-me identificar que o liberalismo se manteve nos pressupostos empiristas da ciência e da moral, apesar da crítica de Kant e sobretudo a de Hegel, mas que, nesse período, eu mal conhecia. ${ }^{52}$

A moralidade kantiana torna novamente objetivo o dever-ser puramente prático da razão - a lei moral do imperativo categórico -, mas se dissocia da função puramente teórica da razão, contrariamente a Aristóteles cujo sistema racional unifica, na metafísica da objetividade do ser, o saber teórico e o prático. O idealismo do espírito absoluto de Hegel vai novamente unificá-los em único e dialético sistema do saber, porém segundo a metafísica da liberdade e não mais, da objetividade do ser. Por isso, a pesquisa me levou ao texto difícil e esquemático de Hegel, orientado sobretudo pelos artigos específicos de Padre Vaz sobre o pensamento hegeliano e seus Escritos de filosofia III e IV.

Hegel restabelece o domínio objetivo da razão moral, a exemplo da práxis aristotélica, mas de acordo com a metafísica da subjetividade da modernidade. No entanto, a metafísica da subjetividade hegeliana não é a de um sujeito atomizado socialmente ou naturalizado, como a metafísica da subjetividade anterior a ele (de Descartes a Fichte), incluindo o racionalismo em geral, o idealismo de Kant e Fichte e o empirismo. A subjetividade hegeliana é a de um ser social - o espírito. É falso, portanto, o dilema entre ser humano individual e social. ${ }^{53} \mathrm{O}$ sujeito hegeliano decorre do espírito, isto é, o espírito

\footnotetext{
${ }^{51}$ Id., $158 / 61$.

52 Id., 165/67.

${ }^{53}$ LIMA VAZ, H.C. A significação da Fenomenologia do Espírito (apresentação) In: HEGEL, G.W.F. Fenomenologia dos Espírito. Petrópolis: Vozes; Bragança Paulista: Editora Universitária
} 
o determina, conforme a inata condição humana da inteligência (razão) e da liberdade, explícita desde a consciência (Fenomenologia do espírito) e implícita no sentimento de si, desde a alma (Enciclopédia das ciências filosóficas).

\section{II}

Foi possível, então, demarcar nesse percurso a prevalência da ética sobre a economia. O modelo hegeliano de eticidade instituiu, para o nosso mestre, a ciência do estado cujo caráter é meta-histórico e, com isso, ultrapassa tanto o modelo liberal quanto a experiência do socialismo real.

No sistema hegeliano do idealismo absoluto, a ideia da liberdade ocupa o centro da relação humana. Por isso, não há vida social sem que prevaleça a consciência da liberdade. Por outro lado, nenhuma ideia se conhece que seja tão indeterminada, equívoca, e capaz dos maiores mal-entendidos, e por isso efetivamente sujeita a eles, quanto a ideia da liberdade, conforme Hegel adverte..$^{54} \mathrm{E}$, segundo alusão que me fez em orientação Padre Vaz, nenhum outro pensador tratou a liberdade com tamanho alcance especulativo como Hegel nos 30 primeiros parágrafos da FD. Tal referência tornou-se imperiosa, partindo de alguém que conhecia a fundo os principais pensadores da filosofia ocidental. A filosofia puramente especulativa da liberdade a que Padre Vaz se referia em Hegel, propõe como "nódulo da especulação" $\mathrm{o}$ "infinito como negatividade" do $\mathrm{Eu}$ "que se refere a si mesmo", "última origem de toda a atividade, da vida de toda a consciência. ${ }^{55}$ É a vontade do Eu não como "sujeito ou substrato já suposto" (Fichte, Schelling), pois, assim, seria uma vontade universal e acabada. Ao contrário, é a vontade como atividade que estabelece sobre si mesma uma mediação a fim de regressar a $s i{ }^{56}$ É a liberdade enquanto dialética da ideia absoluta em si e para si e, como tal, a substância de formação do conceito na Ciência da Lógica que também se expressa no terceiro e último silogismo da filosofia ou ciência do espírito absoluto (\$577) da Enciclopédia das ciências filosóficas. Os trinta parágrafos da FD criticam as acepções de liberdade do subjetivismo moderno, considerando-as não-liberdade ou liberdade negativa, inclusive o livre arbitrio, no marco do que Hegel caracterizou como liberdade do entendimento. Mesmo a metafísica kantiana de liberdade como razão pura prática, Hegel a critica porque a liberdade não é fato da razão, como Kant a considerou, mas dialética ou movimento especulativo, isto é, vontade livre em si que, ao contrário de fato imaginado por Kant, é a inteligência (razão) tornando a

\footnotetext{
São Francisco, 2007. Apresentação extraída do Senhor e escravo; uma parábola da filosofia ocidental. Síntese Nova Fase. Belo Horizonte, v. 8, no 21, p. 7-29, 1981.

${ }^{54}$ HEGEL, G.W.F. Enciclopédia das ciências filosóficas em compêndio, §482.

${ }^{55}$ HEGEL, G.W.F. Fundamentos de la filosofia del derecho, § 7.

${ }^{56} \mathrm{Id}$.
} 
vontade para si. Por não compreender essa dialética absoluta da liberdade, Kant separa sua metafísica da liberdade e ciência, retirando da liberdade sua função teórica. Acaba, assim, separando a razão no seu uso prático e no teórico e não, única razão em movimento dialético ou especulativo concreto em torno de si (em si e para si) que é a ideia da liberdade. Isso permitiu a Hegel colocar a ética ou a liberdade no coração da sua ciência ou filosofia. Seu modelo de eticidade organiza a sociedade política, sua teoria do estado, enquanto consciência da liberdade do cidadão.

Não houve experiência histórica com essa característica teórica. ${ }^{57}$ Isso não se resume ao exemplo das democracias liberais que consideram resolvida a representação popular através de partidos políticos e do equilíbrio dos poderes Executivo, Legislativo e Judiciário. Nem os partidos representam o cidadão, nem os três poderes guardam autonomia para se equilibrarem. É o que mostram as crises recorrentes de representação na sociedade liberal ou capitalista, desde a inauguração do primeiro parlamento na Inglaterra (1688) contra o absolutismo monárquico. Marx analisou, de modo insuperável, os fundamentos econômicos e sociológicos da crise estrutural do capitalismo. No entanto, anteriormente, Hegel fizera a crítica na raiz de todos os fundamentos da sociedade liberal, como apenas a filosofia, segundo ele, é capaz de fazer. A crítica se baseia na falsa concepção de liberdade que o subjetivismo moderno tinha adotado, ao considerar naturalizada ou atomizada socialmente a subjetividade do Eu. A exclusividade do Eu aprisiona a ideia da liberdade dentro de si, alimentando a falsa concepção de que a liberdade se realizaria sem alteridade. Na caracterização de Hegel, ${ }^{58}$ esta é a liberdade de escolha, livre-arbítrio ou liberdade negativa que, na expressão dele, é a anti-liberdade, uma vez que aprisiona o que não pode ser aprisionado, isto é, a manifestação e autorrealização no Eu da ideia de liberdade. Na metafísica hegeliana da liberdade, o Eu é a ideia que implica dialeticamente a alteridade de si do ponto de vista natural e histórico e, portanto, social. Logo, a concepção de uma liberdade encerrada na ideia de si do Eu (subjetivismo) tornou aporética a relação social na modernidade, alimentando as teorias sociais, econômicas, o jusnaturalismo contratualista e o direito positivo, com a falsa concepção de liberdade. Foram esses os alvos da crítica de Hegel, embora a ele sobrevivessem e, para desdouro do humanismo, ainda orientem a ciência e a moral hegemônicas.

$\mathrm{Na}$ teoria hegeliana de estado, não é livre quem vive na sociedade civil, que ele também denominou sociedade burguesa, como é o caso até hoje da humanidade que ainda não é organizada e dirigida pelo cidadão. Tampouco seria livre quem vive no socialismo real cujo aparelho de estado

\footnotetext{
${ }^{57}$ DRUMMOND, Arnaldo Fortes. Paradigmas econômicos e sociológicos de uma ordem humanista. In: BOMBASSARO, Luiz et al. Democracia e inclusão social; desigualdade como desafio para a sociedade e a igreja no Brasil. Bonn/Porto Alegre, CAAD/EDIPUCRS, 2009.

${ }^{58}$ HEGEL, G.W.F. Fundamentos de la filosofia del derecho, § 15.
} 
(burocracia de governo e partido único) usurpa a função política permanente do cidadão. Na sociedade política, o cidadão é a própria instituição política. Os conflitos e impasses não exorbitam do direito público porque são fundamentados na crítica realizando a liberdade no saber como fundamento último da ética.

Dentro desse modelo hegeliano meta-histórico de ciência do estado, é possível hoje vislumbrar o porquê da resposta serena e confiante de Padre Vaz, baseada na ética - à parte, é claro, o alento da fé religiosa, em contraponto à angústia e desesperança que me levaram a procurá-lo em decorrência do meu impasse teórico e existencial.

O modelo hegeliano de estado era, por assim dizer, a filosofia política que respondia aos seus dois respectivos tratados que se complementam antropológica, ética e metafisicamente: Antropologia filosófica I-II e Ética filosófica I-II. O primeiro - dando curso à filosofia e teologia cristãs que fundam a categoria pessoa como imagem e semelhança de Deus - trata essa categoria como núcleo inviolável da dignidade humana na linha de fronteira entre a filosofia e a ciência. Ele sistematiza, portanto, a categoria pessoa, em sua integral e inviolável dignidade, ocupando o centro de construção de sua humanidade. O segundo tratado, integralmente filosófico e complementar ao primeiro, diz respeito essencialmente à inata condição ética da pessoa humana cuja essência é o exercício inviolável da liberdade.

Diante da matriz ética de uma teoria humanista de estado, construída desde a antiguidade clássica e atualizada por Hegel no exercício da ideia da liberdade, é possível concluir que a economia, como organização social para a produção de bens e serviços de uma sociedade, terá uma relação humana de modo exitoso se não seguir regra absoluta, outro princípio objetivo, a exemplo do mercado. O mercado aprisiona a liberdade nos limites da escolha individual e atomizada em disputa por interesse particular. Aprisiona, portanto, o indivíduo no sentimento da vaidade e do extremo orgulho, o que o dessocializa. É a liberdade de uma subjetividade empenhada na melhor solução da alteridade da ideia que se desprendeu de si (natureza e história) mas retorna a si como espírito engrandecido na vivência.

Além disso, o mercado demonstrou que é um sistema moralmente entrópico, porque se organiza desorganizando socialmente na competição o que, a princípio, não tem regra, mas interesse. Além disso, o princípio da competição e não, da reciprocidade ou justiça, concentra socialmente as oportunidades e os resultados, premiando ainda mais os grandes e fortes em detrimento dos fracos e desprotegidos, gerando, afinal, permanentemente, choque e disputa entre indivíduos, conflito entre classes e corporações sociais, guerra e colapso entre classes e nações.

A investigação ética também comprova que o princípio da competição do mercado, justificado como mola propulsora do desenvolvimento, lon- 
ge da neutralidade, como advogam os economistas liberais, é alicerçado moralmente na concepção falsa de liberdade, baseada na subjetividade naturalizada ou atomizada socialmente, segundo o subjetivismo mais exacerbado. A sua matriz é empirista, anglo-saxã e tem como principal expoente Thomaz Hobbes, que se notabilizou pelo emprego da máxima do dramaturgo romano Plautus (254-184 a.C): o homem é o lobo do homem (homo homini lupus). Em sua teoria política, o autor do Leviatã, considera o ser humano naturalmente egoísta e, para viver em sociedade, com seu instinto naturalmente antissocial e violento, necessita do contrato social regido por uma instituição que, despoticamente, tenha poderes acima de todos para coibir a violência individual (o estado Leviatã).

O percurso filosófico trouxe-me a convicção de que, na organização da economia, tudo é, em última instância, convenção, assumida ou imposta eticamente, e não, regra absoluta objetiva como o mercado. Isso vale desde a simples troca até os mecanismos usuais de controle das sociedades complexas, como dinheiro, preço, salário, juro, lucro. No século XX, os dois exemplos emblemáticos de política econômica liberal $-\mathrm{o}$ ortodoxo e o heterodoxo - nos mostraram isso.

O modelo ortodoxo liberal prevalecia quando ocorreu o colapso da bolsa de valores de Nova York em 1929, resultando na quebradeira em cascata mundo afora, com fechamento de fábricas, negócios e milhões de desempregados. Esse modelo acreditava desde o tratado liberal de Smith que o livre mercado por si só se auto equilibra, haja vista que a oferta gera sua própria procu$r a$, conforme se formulou através da lei de Say. ${ }^{59} \mathrm{O}$ colapso desmentiu a lei.

O economista liberal inglês J. M. Keynes (1883-1946) descobriu que, em tais casos, a macroeconomia (a política econômica de um país) pode restabelecer o equilíbrio de mercado da microeconomia, a economia real e privada. A microeconomia seguia a lei de Say, que sempre falhou, mas em geral crise tópica. No entanto, quando a crise atinge certa magnitude, como ocorreu em 1929 e mais recentemente em 2008, a economia entra em colapso. Keynes percebeu haver uma fronteira separando a macroeconomia das regras que regem privadamente as relações econômicas, a microeconomia. E inventou outra regra que consistiu em inverter a regra básica da microeconomia. Ao invés de a oferta condicionar a demanda, a demanda agregada é que gera a sua própria oferta. Como? Fazendo a macroeconomia prevalecer sobre o mercado, isto é, o governo interferir nos negócios econômicos, contratar e financiar obras para gerar novamente empregos, expandindo, com isso, a demanda agregada, estimulando os negócios, a produção e, consequentemente, a oferta. Essa invenção talvez tenha sido a única que realmente inovou o tratado liberal de Adam Smith. Apesar de contrariar

\footnotetext{
${ }^{59}$ Jean-Baptiste Say (1767-1832) foi um economista liberal francês que se notabilizou com a expressão "a oferta cria a sua própria demanda" que define a lei de equilíbrio do mercado em condição de concorrência perfeita.
} 
frontalmente a sua lei de não-interferência no mercado, paradoxalmente, a invenção keneysiana foi capaz de, ao final, salvar a lei de mercado, restabelecendo a normalidade da economia real (microeconomia). Os dois procedimentos, ortodoxo (lei de Say) e heterodoxo (Keynes) mostram não existir lei absoluta de equilíbrio de mercado na própria teoria econômica que a advoga e que, contrariamente a Keynes, reduziu a macroeconomia às regras da microeconomia. Isso apenas reitera, do ponto de vista gnosiológico, o caráter convencional da teoria econômica cujas regras são relativas, respectivamente, à macro ou microeconomia.

A teoria liberal keynesiana prevaleceu nas políticas econômicas dos estados liberais do pós-guerra até o início dos anos 1980. Ela levou à intervenção do estado na economia, promoveu o pleno emprego, a demanda agregada e o bem-estar social (welfare state). Trouxe prosperidade econômica e social à economia mundial. $\mathrm{O}$ Brasil expandiu sua infraestrutura urbana e viária, criou indústria de base (petróleo, eletricidade e química), de bens de capital (máquinas e equipamentos), de bens de consumo duráveis e alimentos, internalizando o ciclo industrial completo daquele período e deixou de ser uma economia monocultora, baseada essencialmente na produção de bens primários (agricultura e mineração). Nesse período de aproximadamente 40 anos, o Brasil conseguiu o prodígio de liderar mundialmente o crescimento médio anual de $7 \%$ do PIB. No entanto, a invenção keynesiana, como alternativa liberal, não remove o caráter essencialmente conflituoso e injusto da sociedade civil, segundo Hegel, ou da exploração capitalista, segundo Marx. Não pôde evitar a crise econômica internacional que eclodiu em meados dos anos 70, atribuída basicamente a alta brusca do preço do petróleo, que gerou o fenômeno conhecido como estagflação (estagnação + inflação).

O Consenso de Washington (1989), que reuniu lideranças das principais economias capitalistas, atribuiu a culpa pela estagflação daquele período ao receituário keynesiano e indicou o retorno ao receituário ainda mais ortodoxo de livre mercado e estado mínimo, conhecido como neoliberalismo. Ele ainda prevalece.

Em síntese, foram adotadas as políticas macroeconômicas de arrocho fiscal, monetário e autonomia do Banco Central. Essa autonomia se resume na privatização da moeda, isto é, o controle da moeda e do câmbio é realizado pelas forças de mercado, o sistema bancário e financeiro. Com isso, a macroeconomia foi destituída de sua principal função que é o controle monetário do Estado através do qual são gerados diretamente (sem intermediação privada do sistema bancário e financeiro $)^{60} \mathrm{o}$ investimento e

\footnotetext{
${ }^{60} \mathrm{O}$ controle monetário pelo Estado, através de um Banco Central dirigido pelo Governo, pode gerar o financiamento público diretamente pelo Tesouro Nacional através, por exemplo, de um banco de desenvolvimento estatal, que, a princípio, não tem finalidade lucrativa e, por isso, não cobraria juros. No caso brasileiro, já há o banco de desenvolvimento (BNDES) e a Caixa Econômica que são inteiramente estatais, embora erroneamente assumam caráter privado e cobrem juros. O Banco do Brasil não vem ao caso porque é sociedade anônima, embora o acionista majoritário seja o estado.
} 
financiamento públicos quando há crise no mercado ou baixo crescimento da microeconomia.

A moeda é um bem público, o mais universal dos bens materiais ao alcance de todos, pois representa o valor material das coisas, o equivalente geral das coisas materiais de uma sociedade, na clássica definição de Aristóteles ${ }^{61}$ Por isso, todas as transações econômicas de determinado país têm como referência de valor a sua moeda ou a moeda que adotou. Sem essa confiança universal de todos na moeda, não ocorreriam as transações econômicas de uma sociedade complexa. Todavia, o fundamento (lastro) dessa confiança na moeda que lhe confere caráter público é o Estado que a patrocina ou federação de estados, como o Euro, da União Europeia. ${ }^{62}$ Por isso, é legítima e necessária a tutela do Estado sobre a moeda.

Entretanto, não é isso que ocorre nas economias capitalistas atuais geridas pelo receituário neoliberal. A moeda deixou de ser tutelada pelo Estado, e sim pelo mercado bancário financeiro. Ou seja: o acesso à moeda foi privatizado. É um dos grandes paradoxos do neoliberalismo: o Estado que patrocina a moeda e lhe garante a confiança entre todos, inclusive as instituições bancárias e financeiras privadas, não tem acesso direto à moeda. Quando precisa dela para investir ou financiar a economia ou sair de uma crise, e não tendo recursos orçamentários e tributários suficientes, o Estado tem de pedir emprestada a sua própria moeda aos bancos e ao mercado financeiro. E pagará a essas instituições privadas os juros sobre a sua própria moeda 'emprestada.' O Estado que tem o poder real de emitir a sua moeda como real tutor da confiança monetária, tem de transferir à intermediação financeira privada o seu poder legal de emiti-la, segundo o receituário neoliberal. Para isso essa teoria criou o falso conceito de autonomia do Banco Central. Não há autonomia, e sim dependência completa do Banco Central às regras do mercado financeiro que passam a controlar privadamente a moeda, bem público por excelência. Essa é a raiz da dívida pública interna, outro paradoxo da receita neoliberal: o Estado torna-se devedor de si próprio. Como isso é possível?

Deixando de lado os aspectos técnicos especializados, que não vêm ao caso, o artifício em tese é o seguinte: 1) o Banco Central "autônomo" e o Tesouro Nacional são duas instituições públicas; 2) o Banco Central "autônomo" relaciona-se com as instituições do mercado financeiro, comercializando os títulos da dívida pública que são emitidos pelo Tesouro Nacional; 3) o

${ }^{61}$ DRUMMOND, Morte do mercado, cap. 4.

${ }^{62}$ Tem sido assim até hoje, embora haja explosão de criptomoedas, lideradas pelo bitcoin, as quais aparentemente não têm lastro por não estarem ligadas a país, economia, empresa, entre outras fontes de patrocínio. No entanto, sem a confiança ou crença na confiança, que é uma forma de lastro, não há como a criptomoeda sobreviver. A questão que se coloca é: uma crença, embasada apenas na confiança, sem algo sólido que a patrocine, perdura indefinidamente, ou se esfuma com um choque especulativo que, neste caso, é sempre possível ocorrer? 
Tesouro Nacional, que tem o poder oficial de emitir moeda, passa a não mais fazê-lo, segundo a receita neoliberal, a não ser residualmente para recomposição dos estoques monetários (base monetária); 4) esses títulos são notas promissórias oficiais repassadas ao Banco Central para a comercialização direta com o mercado financeiro; 5) o Tesouro se compromete a resgatar essas promissórias, mediante um prêmio ou juros pagos às instituições financeiras compradoras, no ato de comercialização; 6) o mercado financeiro repassa a moeda correspondente ao valor da nota promissória e torna-se, com isso, credor do governo. Essa dívida chega hoje no Brasil a quase $90 \%$ do PIB e, o mais grave, compromete em torno de $50 \%$ do orçamento público anual. Por isso, os bancos não têm prejuízos, mesmo diante da maior crise que o país já passou. O receituário neoliberal, que recomenda a intermediação financeira da moeda através do mercado, não vê nenhuma função no banco público ou estatal. Donde a pressão do mercado financeiro para venda dos bancos estatais brasileiros.

Em menos de 30 anos, os resultados do neoliberalismo foram calamitosos.

Do ponto de vista econômico e social, o colapso de 2008 foi mais intenso que a queda da bolsa em 1929. Houve concentração brutal de renda que alimentou ainda mais o controle financeiro da economia real. A financeirização da economia potencializa crises futuras ainda mais avassaladoras, em função do distanciamento entre a economia real e a financeira. Os direitos sociais e trabalhistas, secularmente conquistados pela luta sindical, em especial durante o período de pleno emprego (welfare state), com progresso na distribuição de renda e melhores condições de vida e trabalho, estão hoje condenados ao desaparecimento. Além disso, cresce a legalização da informalidade, sobretudo mediante o fenômeno da uberização, com jornada de trabalho de 10 a 15 horas por dia, como não se via desde final do século XIX, sem férias e folga semanal, décimo terceiro salário e aposentadoria.

O colapso econômico de 2008 acendeu a luz amarela para os líderes e governantes mundiais em relação ao receituário neoliberal. Eles foram obrigados a rasgar os manuais ortodoxos e intervir maciçamente no mercado, como foi o caso da principal economia capitalista (EUA) que injetou na economia real de 3 a 4 trilhões de dólares de recursos públicos. A pandemia Covid19 reforçou ainda mais o alerta de que os financiamentos e investimentos públicos são essenciais ao funcionamento econômico. Os estados não se reduzem a meras agências reguladoras, como dizem esses manuais, mas têm de ser dotados de equipamentos e aparelhos cada vez mais sólidos para atuação direta na Economia, como é urgente na saúde pública e auxílio emergencial, na atualidade.

A receita neoliberal acabou com a fronteira teórica entre a macro e a microeconomia. Keynes e os economistas que veem a função e o controle públicos da moeda sabem que as regras que regem a macroeconomia não podem ser as mesmas da microeconomia. A macroeconomia é necessaria- 
mente regida pela função pública da moeda que não está sujeita a regra imediata do mercado, mas, ao contrário, à correção dos seus desequilíbrios que ele gera, sobretudo em relação ao progresso, à distribuição de renda e ao pleno emprego, finalidades essenciais de uma política econômica. $\mathrm{O}$ fundamento desses objetivos é, portanto, de natureza ética. A microeconomia, porque visa ao interesse imediato, pode seguir a regra de mercado, mas a macroeconomia, como política econômica de Estado, não, porque visa ao interesse público.

\section{III}

Em relação à teoria de estado, Hegel propõe, como compete à filosofia, uma teoria humanista de estado e, portanto, universalmente válida para os nossos dias. Em vários escritos, Padre Vaz afirma que a teoria de estado hegeliana superou, além da teoria liberal, o pensamento de Marx que não fez propriamente teoria de estado, mas a deixou subentendida $\mathrm{n}^{\prime} \mathrm{O}$ capital e outros escritos, através da sua crítica sociológica ao capitalismo ou, segundo sua expressão, crítica da economia política.

Em sua teoria humanista de estado, Hegel sistematiza os elementos de uma ciência absoluta do estado na qual a liberdade é a chave heurística e hermenêutica de sua construção. E faz a crítica de toda acepção subjetivista de liberdade.

Hegel parte do ser humano integrado socialmente no próprio exercício subjetivo da razão e da liberdade. São as respectivas condições subjetivas que integram socialmente o indivíduo através do saber (gnosiológico) e da moral (vida ética). A subjetividade hegeliana, por isso, ao contrário de subjetivista ou autocentrada, assume a condição universal de espírito.

Marx herda a concepção hegeliana de ser humano social, porém reduz a sociabilidade hegeliana apenas ao exercício da razão determinada pela práxis. Em seu materialismo histórico, a sociabilidade, por ele denominada práxis, é determinada pelas forças produtivas e relações sociais de produção (modo de produção). Desse modo, o social de Marx decorreria apenas de um sujeito mediado pela razão no mundo do trabalho (modo de produção), eliminando, então, desse sujeito histórico social, a liberdade subjetiva que lhe é determinante, segundo Hegel. Sem esta condição inalienável, o sujeito de Marx tornou-se, afinal, instrumentalizado pelas práxis. É o principal equívoco do materialismo histórico de Marx, na avaliação de Padre Vaz: o mundo do trabalho, por mais essencial e importante, não substitui a função determinante da liberdade como mediadora da relação social. Ele desfaz a chave heurística e hermenêutica de um modelo universal de estado. Pois 
não se isola socialmente o sujeito em sua inata liberdade na construção, em caráter definitivo como convém à filosofia ou ciência, da teoria de estado. Marx errou, ao condicionar determinantemente o sujeito ao seu contexto econômico social. Assim ele deixou de fazer filosofia e passou a fazer uma ciência especializada a esse contexto, que não tem evidentemente o alcance universal como pretendia seu materialismo histórico. Ele próprio reconhece a troca da filosofia pela abordagem especializada, embora atribua erroneamente ao materialismo histórico (modo de produção) o caráter universal de teoria da história. ${ }^{63}$

Hegel vê no subjetivismo a raiz do erro que considera a liberdade individual isolada socialmente e, segundo a sua crítica, essa raiz está em toda tradição do pensamento moderno, desde Descartes. Ele rompe com essa tradição e a tipifica como liberdade do entendimento ou, em Kant, fato da razão pura prática. Como entendimento, a liberdade tem acepção de escolha. É a liberdade, como ele afirma, abstrata, ou negativa, ou do livre arbítrio. Como tal, é a anti- liberdade, uma vez que está presa ao subjetivismo ou ilusão de isolamento social. Tampouco a liberdade é o fato da razão pura prática que se efetiva na moral kantiana. Nesta acepção, a moral é formal e abstrata porque mantém a perspectiva do sujeito isolado histórica e socialmente. A acepção verdadeira de liberdade é uma descoberta hegeliana. Ela é concreta e se efetiva na subjetividade inserida socialmente, mas sempre ultrapassada como ideia absoluta da liberdade em si e para si. $\mathrm{Na}$ expressão de Padre Vaz, a metafísica da liberdade hegeliana, ao mesmo tempo moral e gnosiológica, e que se efetiva em qualquer circunstância social e histórica, é que vai permitir ao cidadão buscar e concordar com a resposta mais universal através da sociedade política ou do estado ético. Essa é a liberdade que determina a teoria hegeliana humanista de estado.

Enfim, em nome da vida e dignidade humana, temas caros à ação pública de governo, a resposta ética acaba impondo-se à organização humana em geral e à economia, em particular. Melhor seria se tal resposta viesse pela filosofia, como Padre Vaz vislumbrou na atualidade da teoria hegeliana de estado, mas de toda forma a resposta ética se impõe à economia, ainda que pela via da crise recorrente, luta e sofrimento.

Se há 30 anos o procurei, ansioso para sair do impasse em que me encontrava, e ele, inabalado e profundo mestre, apontou o roteiro, é porque, nós os aflitos, passamos. Mas os mestres ficam! Ficam para guiar os acontecimentos. Eternamente. Por isso, nós o homenageamos, e outros certamente o farão.

\footnotetext{
${ }^{63}$ Os filósofos têm apenas interpretado o mundo de maneiras diferentes; a questão, porém, é transformá-lo. K. Marx, 11 $1^{\underline{a}}$ Tese sobre Feuerbach. In: George Labica. As "teses sobre Feuerbach" de Karl Marx, Rio de Janeiro: Zahar editores, 1990.
} 


\section{Bibliografia}

ARISTÓTELES. Economia doméstica. In: Obras completas. Madrid: Aguilar, s/d. ARISTÓTELES. Ética a Nicômaco. Trad. L. Vallandro e G. Bornheim. São Paulo: Abril Cultural, 1979 (Os pensadores).

ARISTÓTELES. Politica. In: Obras completas. Madrid: Aguilar, s/d.

DRUMMOND, Arnaldo Fortes. Ética e Economia; abordagem da ontologia do agir econômico. Belo Horizonte: Fafich/UFMG, 1997. (Dissertação de mestrado em Filosofia).

DRUMMOND, Arnaldo Fortes. Liberdade e economia na Filosofia do Direito de Hegel. Síntese. Belo Horizonte, v. 33, nº 107, 2006.

DRUMMOND, Arnaldo Fortes. Morte do mercado: ensaio do agir econômico. São Leopoldo: Ed. Unisinos, 2004.

DRUMMOND, Arnaldo Fortes. Paradigmas econômicos e sociológicos de uma ordem humanista. In: BOMBASSARO, Luiz et al. Democracia e inclusão social; desigualdade como desafio para a sociedade e a igreja no Brasil. Bonn/Porto Alegre, CAAD/ EDIPUCRS, 2009.

HEGEL, G.W.F. Enciclopédia das ciências filosóficas, em compêndio; 1830. Trad. Paulo Menezes. São Paulo: Loyola, 1995. (O pensamento ocidental).

HEGEL, G.W.F. Fundamentos de la filosofia del derecho. Edición: K.H.Ilting. Madrid: Libertarias/Prodhufi, 1993.

HOBBES, Thomas. Leviatã. São Paulo: Nova Cultural, 1988.

HUME, David. Investigação sobre o entendimento humano. Lisboa: Edições 70, 1989. KANT, Imanuel. Fundamentação da metafísica dos costumes. Lisboa: Edições 70, 1964.

LIMA VAZ, H.C. A formação do pensamento de Hegel. São Paulo: Loyola, 2014. (Obra filosófica inédita de Henrique Cláudio de Lima Vaz. Organização, edição e apresentação: Arnaldo Fortes Drummond).

LIMA VAZ, H.C. A significação da Fenomenologia do Espírito (apresentação) In: HEGEL, G.W.F. Fenomenologia dos Espírito. Petrópolis: Vozes; Bragança Paulista: Editora Universitária São Francisco, 2007.

LIMA VAZ, H.C. Escritos de filosofia III. Filosofia e cultura. São Paulo: Loyola, 1997.

LIMA VAZ, H.C. Escritos de filosofia IV; introdução à Ética filosófica 1. São Paulo: Loyola, 1999.

LIMA VAZ, H.C. Introdução ao pensamento de Hegel. São Paulo: Loyola, 2020. (Obra filosófica inédita de Henrique Cláudio de Lima Vaz. Organização, edição e apresentação: Arnaldo Fortes Drummond).

LIMA VAZ, H.C. Marxismo e filosofia. Rev. Síntese Política, Econômica e Social. Rio de Janeiro, n. 1,2,3, 1959.

LIMA VAZ, H.C. Modelo historicista: o idealismo alemão e a ética de Hegel. In: LIMA VAZ, H.C. Escritos de filosofia IV; introdução à ética filosófica 1. São Paulo: Loyola, 1999. 
LIMA VAZ, H.C. Ontologia e história. São Paulo: Duas cidades, 1968.

LIMA VAZ, H.C. Senhor e escravo; uma parábola da filosofia ocidental. Síntese Nova Fase. Belo Horizonte, v. 8, no 21, p. 7-29, 1981.

Lisboa: Calouste Gulbenkian, 1993, 2 v.

MARX, Karl. Manuscritos econômico-filosóficos. São Paulo: Boitempo editorial. 2004.

MARX, Karl. O capital. São Paulo: Boitempo editorial. Livros [I, II, III]. [2011, 2014, 2017].

PLATON. Les lois. In: Oeuvres complètes. Trad. Léon Robin. Paris: Gallimard, 1994, 2 v.

SILVA, F.L. Filosofia e forma de ação. Uma entrevista de Henrique Cláudio de Lima Vaz. In: Cadernos de filosofia alemã. São Paulo, no 2 (jun. 1997), 77-102.

SMITH, Adam. Riqueza das nações. 3aㅡ ed. Trad. Teodora Cardoso e Luís Cristóvão de Aguiar. Lisboa: Calouste Gulbenkian, 1993, 2 v.

SMITH, Adam. Teoria dos sentimentos morais. Trad. Lya Luft. São Paulo: Martins Fontes, 1999.

Endereço do Autor:

Rua Fernando Teotônio da Costa, 96

Bairro Aldebarã

Cachoeira do campo - distrito

35410-000 Ouro Preto - MG

sdrummond@terra.com.br 